\title{
MIMR $\mid$ PSYCHOLOGICAL STRESS AND LONG-TERM RISK OF TYPE 2 DIABETES MELLITUS AMONG CIVIL SERVANT: A PROSPECTIVE COHORT STUDY
}

\author{
Aulia Putri, Junaidy Suparman Rustam \\ Yarsi Health Science College, Bukittinggi, West Sumatra, Indonesia \\ *Correspondence Author's Email: aulia_2803@yahoo.com
}

\begin{abstract}
Background: The high incidence rate of Diabetes Mellitus (DM) among Indonesian productive age populationsignificantly affects the quality of the human capital in this country. Thus, it is highly necessary to manage and to prevent the onset of DM by identifying its risk factors, both direct and indirect ones. One of these factors is psychological stress, which triggers increased level of the body's fight-or-flight hormone making the body release extra energy in the form of glucose and fat into cells. The long term psychological stress prevents the insulin fromenabling the extra energy to be absorbed into the cells thereby leading the glucose to build up in the blood. Therefore, it is important to identify the psychological stress in the attempt to avoid the future incidence of DM. Objective: To determine the association between psychological stress and risk of type $2 \mathrm{DM}$ among male and female civil servants. Methods: A prospective cohort study was conductedin 190 participants (aged 26-45 years) of six civil department services in Bukittinggi city, West Sumatra Indonesia. Data were collected for 3 times measurements by using Depression, Anxiety, Stress Scale (DASS)and Framingham Offspring Type 2 Diabetes Risk Score (FRS). The Spearman rho was used to analyze the inferential statistic. Results: Result of the study showed there was a strong relationship between psychological stress and the risk of type $2 \mathrm{DM}$ at baseline $(\mathrm{RR}=0.46, p<.05)$ and the coefficient of determinant showed $22 \%$. Same as on 2 nd and $3^{\text {rd }}$ measurements were found that the p-values are $<.05$, while the determinant coefficient were $33 \%$ and $19 \%$, respectively. Conclusion: The evidence reflected that a long term stress or uncontrol psychological stress for a sufficiently long period might disturb insuline regulation in the body, which in turn increases the risk of developing type $2 \mathrm{DM}$, especially on productive aged.
\end{abstract}

\section{Keywords: Psychological Stress, Risk of Type 2 Diabetes Mellitus, Productive Aged}

\section{INTRODUCTION}

The high incidenceof diabetes mellitus (DM) in Indonesia potentially affects to the quality of future human capital. The amount of health cost spent for a minimum-standard DM care is estimated at 1.5 billion rupiah per day or around 500 billion rupiah per year. Therefore, it is highly necessary tomanage and to prevent the incidence of DM by focusing on risk factors that directly or indirectly cause it (PERKENI, 2015).DM is a chronic endocrine disorder triggered bythe increased level of glucose in the blood. It has been reported that most (approximately 90\%) of the total DM cases are type 2 DM (Widodo, 2012) and there has been an increasing incidence of DM in Indonesiaamong the productive age population
(Anggina, Ali, Pandhit, 2010). WHO (2017) predicts the number of people with DM in Indonesia will increase from 8.4 million to around 21.3 million in 2030. Furthermore, it can be estimated that around 50\% people with DM areundiagnosed in Indonesia.

There were two types of DM risk factors,modifiable risk factors including diet, resting patterns, activity patterns, and stress management and non-modifiable factors such as age, gender, history of DM in the family(Isnaini \& Ratnasari, 2012). American Diabetic Association (ADA)stated thatpsychological stress as one of modifiable risk factor of DM should be a great concern to prevent the occurrence of type $2 \mathrm{DM}$ in the future (ADA, 2017).

It is almost impossible to avoid psychological stress in 
the daily life due to every daily activity that may lead stress with different extentsuch as marriage, work, health, or financial problems (Siregar \& Hidajat, 2017). Ideally, human body can tolerate with physical, emotional, or mental stress for a limited lenghth of time,so the expreriances of psychological stress in long period contributes the occurance of certain disease, including type $2 \mathrm{DM}$.

Previous study found that people who experienced psychological stress frequently was more likely to develop type 2 diabetes melitus in the future (Errikson, et al., 2008). Anotherstudy also found that people with high level of psychological stress was 33\% more likely to experience metabolic disorders including type $2 \mathrm{DM}$ rather than those with low level ofpsychological stres. Psychological stress triggers increased levels of the body's fight-or-flight hormone which causes the body to release extra energy in the form of glucose and fat for cells. These cells are then provoked to help the body avoid harm. However, this fight-or-flight response among people who are at risk for type 2 DM may not work properly. The constant psychological stress will hinder the insulin to allow the extra energy to be absorbed into the cells thereby leading the glucose to build up in the blood.

\section{Objective}

This study aims to analyze and compare psychological stress levels with long-term risk of type 2DMamong productive aged who working at civil department services over 3 time periods.

\section{METHODOLOGY}

\section{Study Design}

This studywas useda prospective cohort design. The participants were recruited fromsix civil department Bukittinggi City, West Sumatra, Indonesia from Februari to September 2020.The inclusion criteria were (1) age 26-45 years (2) agreed to be a respondent, the exclusion criteria were (1)have diagnosed Diaebetes Mellitus, (2) have a cognitive or hearing impairment.

\section{Sample}

The sample size was calculated by using a cohort sample calculation formula to test the hypothesis against the relative risk. The sample was obtained as many as 190 people.Stratified random sampling technique was performed to selecting the participant of each civil department services in this atudy.

\section{Measurements}

The instrument that has been used in this study including 1)DASS (Depression, Anxiety, Stress Scale). This tool was adopted from Lovibond (1995) which consisted of 42 items to asses and determine the level of psychological stress, and2) FRS (Framingham Offspring Type 2 Diabetes Risk Score) by Virtanen, et al.(2014) which consisted of six indicators to assess long-term risk of type $2 \mathrm{DM}$ in this study.

\section{Data Collection}

Data were collected for three times, on February 2020 asthe base line, then on June and September as the follow up data.

\section{Analysis}

Descriptive statistics were used to analyze and describe demographic characteristics of the participants. Spearmen rho was performed to detect any significant relationship between the variables.

\section{RESULTS}

The demographic data of the participants were shown in Table.1. Result of the study showed psychological stress in high category is more prevalent in women than men in the average age of 39.39 years old. In addition, the stress (low, moderate or high) is more prevalent in the group of respondents who are not married than those married. Meanwhile, seen from the educational level, the incidence of stress is more prevalent in the group of senior high school graduates than those of the college. Finally, seen from the category of occupational position and employment length, the respondents with structural positions have been in high catagory of psychological stress than functional positions. The average of respondents' working experience for high category is 17.67 years 
Tabel 1: Characteristics and levels of psychological stress at baseline February 2020 ( $N=190)$

\begin{tabular}{|c|c|c|c|c|c|c|c|c|}
\hline & \multicolumn{8}{|c|}{ Level of Psychological Stress } \\
\hline & \multicolumn{2}{|c|}{ normal $(n=117)$} & \multicolumn{2}{|c|}{ low $(n=51)$} & \multicolumn{2}{|c|}{ moderate $(n=16)$} & \multicolumn{2}{|c|}{ high $(n=6)$} \\
\hline & f & $\%$ & f & $\%$ & f & $\%$ & f & $\%$ \\
\hline Age, mean (SD) & $M=39,62$ & $\mathrm{SD}=5,58$ & $\mathrm{M}=39.39$ & $\mathrm{SD}=4,39$ & $M=40,13$ & $\mathrm{SD}=4,22$ & $M=39$ & $\mathrm{SD}=4,94$ \\
\hline \multicolumn{9}{|l|}{ Sex } \\
\hline Male & 41 & $58,6 \%$ & 22 & $31,4 \%$ & 3 & $4,3 \%$ & 4 & $5,7 \%$ \\
\hline Female & 76 & $63,3 \%$ & 29 & $24,2 \%$ & 13 & $10,8 \%$ & 2 & $1,7 \%$ \\
\hline \multicolumn{9}{|l|}{ Marriage status } \\
\hline Marriage & 14 & $82,4 \%$ & 3 & $17,6 \%$ & 0 & 0 & 0 & 0 \\
\hline Unmariage & 103 & 59,5 & 48 & $27,7 \%$ & 16 & $9,2 \%$ & 6 & $3,5 \%$ \\
\hline \multicolumn{9}{|l|}{ Level of education } \\
\hline Higher education & 47 & $62,7 \%$ & 20 & $26,7 \%$ & 7 & $9,3 \%$ & 5 & $4,3 \%$ \\
\hline Primary education & 70 & $60,9 \%$ & 31 & $27 \%$ & 9 & $7,8 \%$ & 5 & $4,3 \%$ \\
\hline \multicolumn{9}{|l|}{ Job Position } \\
\hline Structural & 97 & $68,3 \%$ & 38 & $26,8 \%$ & 6 & $4,2 \%$ & 1 & $0,7 \%$ \\
\hline Fungsional & 20 & $41,7 \%$ & 13 & $27,1 \%$ & 10 & $20,8 \%$ & 5 & $10,4 \%$ \\
\hline Working experience & $M=17,71$ & $\mathrm{SD}=8,27$ & $M=17,53$ & $\mathrm{SD}=7,15$ & $\mathrm{M}=15,95$ & $\mathrm{SD}=6,24$ & $M=17,67$ & $\mathrm{SD}=6,86$ \\
\hline
\end{tabular}

Then, the comparison of psychological stress levels with component risk factors of Type $2 \mathrm{DM}$ were shown in Table 2. Result of study showed thatthe average of fasting glucose is 95.91 in normal situation (not stress) and 157.17 in high level category. Similary,the different tren is also found in the respondents' average BMI depending on their level of psychological stress (normal, low, moderate or high), in which the heavier the stress the higher the BMI. Furthermore, related to HDL levels, the table shows that the heavier the stress, the higher the HDL value. Triglyceride levels howed that the higher the stress level, the higher the triglyceride level. Furthermore, regarding systole and diastole level, the table indicates that the higher the stress level, the higher the systole and diastolic values.

Table 2: Comparison of Psychological stress levels with component risk factors of Type 2 DM based on FRS at baseline February $2020(\mathrm{~N}=190)$

\begin{tabular}{|c|c|c|c|c|c|c|c|c|c|c|c|c|c|c|}
\hline \multirow{3}{*}{$\begin{array}{l}\text { Level of } \\
\text { Psychologi } \\
\text { cal Stress }\end{array}$} & \multicolumn{14}{|c|}{ FRS } \\
\hline & \multicolumn{2}{|c|}{ Fasting Glucose } & \multicolumn{2}{|c|}{ BMI } & \multicolumn{2}{|c|}{ HDL-C Level } & \multicolumn{2}{|c|}{$\begin{array}{c}\text { Parental history of } \\
\text { DM }\end{array}$} & \multicolumn{2}{|c|}{ Triglycerida Level } & \multicolumn{2}{|c|}{ BP (Sistole) } & \multicolumn{2}{|c|}{ BP(Diastole) } \\
\hline & Mean & SD & Mean & SD & Mean & SD & Yes & No & Mean & SD & Mean & SD & Mean & SD \\
\hline Normal & 95,91 & 11,59 & 27,95 & 1,45 & 55,34 & 8,66 & $77(65,8 \%)$ & $37(31,6)$ & 131,50 & 20,56 & 129,97 & 13,60 & 83,39 & 4,96 \\
\hline Low & 112,43 & 32,45 & 28,17 & 1,48 & 56,84 & 8,25 & $35(68,6)$ & $16(31,4)$ & 125,27 & 18,13 & 125,24 & 16,11 & 81,63 & 5,30 \\
\hline Moderate & 109,75 & 12,11 & 27,63 & 1,36 & 58,75 & 5,36 & $11(68,8)$ & $5(31,3)$ & 122,19 & 17,23 & 127,19 & 6,92 & 82,63 & 3,98 \\
\hline High & 157,17 & 87,3 & 28,18 & 1,72 & 60,17 & 2,71 & $1(16,7 \%)$ & $5(83,3)$ & 135,97 & 17,84 & 133,17 & 8,91 & 84,67 & 3,20 \\
\hline
\end{tabular}

Furthermore,therelationship between psychological stress and the risk of type $2 \mathrm{DM}$ (table 3 ) showed that there is a relationship between psychological stress and the risk of developing type 2 diabetes mellitus in whichthe first measurement obtained $\mathrm{p}$-value $=0.000, \mathrm{RR}=0.464$ and coefficient of determinant $=22 \%$. Thus, there is a significant relationship of psychological stress and the risk of type 2 diabetes mellitus. Likewise,onthe 2nd and 3rd measurements, the obtained $\mathrm{p}$ value $=0.000, \mathrm{RR}=0.576$, the determinant coefficient of $33 \%$ for 2 nd test and the obtained $\mathrm{p}$ value is also 0.000 with $\mathrm{RR}=0.434$, the determinant coefficient of $19 \%$ for the $3 r d$ test. 
Table 3.The Relationship between Psychological Stress and the Risk of Type 2 DM

\begin{tabular}{|c|c|c|c|c|c|c|}
\hline \multirow{2}{*}{$\begin{array}{l}\text { Level of Psychological } \\
\text { Stress: }\end{array}$} & \multicolumn{3}{|c|}{ Risk of Type 2 Diabetes Melitus } & \multirow{2}{*}{$P$ value } & \multirow{2}{*}{$\mathbf{R R}$} & \multirow{2}{*}{ CD } \\
\hline & Low & Moderate & High & & & \\
\hline \multicolumn{7}{|c|}{$1^{\text {st }}$ Measurement I $(n=190)$} \\
\hline Normal & $44(54.3 \%)$ & $37(45.7 \%)$ & $0(0 \%)$ & \multirow{4}{*}{0.000} & \multirow{4}{*}{0.464} & \multirow{4}{*}{$22 \%$} \\
\hline Low & $4(12,1 \%)$ & $28(84,8 \%)$ & $1(3.0 \%)$ & & & \\
\hline Moderate & $1(8.3 \%)$ & $10(83.3 \%)$ & $1(8.3 \%)$ & & & \\
\hline High & $0(0 \%)$ & $4(80 \%)$ & $1(20 \%)$ & & & \\
\hline \multicolumn{7}{|c|}{$2^{\text {nd }}$ Measurement $(n=184)$} \\
\hline Normal & $54(58,1 \%)$ & $38(40,9 \%)$ & $1(1,1 \%)$ & \multirow{4}{*}{0.000} & \multirow{4}{*}{0.576} & \multirow{4}{*}{$33 \%$} \\
\hline Low & $1(4.0 \%)$ & $23(92.0 \%)$ & $1(4.0 \%)$ & & & \\
\hline Moderate & $1(1.6 \%)$ & $61(96.8 \%)$ & $1(1.6 \%)$ & & & \\
\hline High & $0(0 \%)$ & $2(66.7 \%)$ & $1(33.3 \%)$ & & & \\
\hline \multicolumn{7}{|c|}{$3^{\text {rd }}$ Measurement III $(n=182)$} \\
\hline Normal & $85(91.4 \%)$ & $8(8.6 \%)$ & $0(0 \%)$ & \multirow{4}{*}{0.000} & \multirow{4}{*}{0.434} & \multirow{4}{*}{$19 \%$} \\
\hline Low & $19(86.4 \%)$ & $2(9.1 \%)$ & $1(4.5 \%)$ & & & \\
\hline Moderate & $28(52.8 \%)$ & $19(35.8 \%)$ & $6(11.3 \%)$ & & & \\
\hline High & $1(7.1 \%)$ & $6(42.9 \%)$ & $7(50.0 \%)$ & & & \\
\hline
\end{tabular}

\section{DISCUSSION}

Study showed that there is a contradictsbetween theories and the result about HDL-c levels. Result of study showed that the heavier the stress, the higher the HDL value. Then, this is also applying to trygliceride levels that the higher the stress level, the higher the triglyceride level.

HDL or High Density Lipoprotein is a lipoprotein that contains more protein and less fat, which functions as a cholesterol carrier from the tissues to the liver for metabolic processes. HDL is also referred to as good fat (Ridayani, Santri, \& Naim (2018). Several studies have linked individuals' stress response with HDL, LDL, and triglyceride level. The study by Marcondes, et al., (2018) states that the increased cortisol levels due to stress can increase serum levels of total cholesterol, LDL, triglycerides but decrease HDL serum levels (Yoo, H. \&Franke, WD (2010).As for triglyceride level, the table showed that the higher the stress level, the higher the triglyceride level. This is relevant with many studies explain that the relationship of psychological stress and increased lipid metabolism. Marcondes, et al., (2019) states that the increase in basal cortisol concentrations and variability of circadian cortisol among respondents with stress causes dyslipidemia.
The increased cortisol levels increases serum levels of total cholesterol, LDL, triglycerides, and decreases HDL level. Furthermore, regarding systole and diastole level, the table indicates that the higher the stress level, the higher the systole and diastolic values.

Chronic stress triggers changes in the immune system. Activation of the immune system provokes neuroendocrine and neurotransmitter changes (Heraclides et al., 2009). Stress causes an overproduction of cortisol, a hormone that counteracts the effects of insulin and causes high blood sugar level. If a person experiences severe stress for a long time, thecortisol will increasesignificantly, and it will reduce the body's sensitivity to insulin. Labindjang, Kadir, \& Salamanja's research (2015) states that stress is a factor with an important effect on diabetes due to an increase in stress hormones increasing blood sugar levels. The research by Harris, et al., (2017) reveals that stress is a strong risk factor for the occurrence of type $2 \mathrm{DM}$ in the future. The pathophysiological mechanisms to explainthe relationship of psychological stress and diabetes mellitus risk are direct neuroendocrine effect (the fact that stress hormones such as cortisol and adrenaline are against insulin regulation) and indirect effect (e.g. stress can reduce mood to do exercise, maintain diet and practice healthy lifestyle). Harris, et 
al., (2017) describe an Australian study which found that women aged 25 and above with frequent psychological stress experienced abnormal glucose metabolism over five year periods.

However, the research by Sui, et al., (2016) confirms thatthe hypothesis "psychological stress increases the risk of type 2 diabetes" cannot be proven. That the work stress can increase the risk of type 2 diabetes in women but not in men is proven only in the subgroup analysis. This study also explains that in the future the occurrence of type 2 diabetes will involve multiple factors instead of one factor only.Another study suggests that the relationship between psychosocial factors and type 2 diabetes may be complex. Long-term stress triggers the body to produce the hormone epinephrine, also known as adrenaline. The hormone epinephrine is usually produced by the body as a physiological response to danger, being attacked, and trying to survive. This condition is called fight-or-flight response. Epinephrine raises blood sugar by increasing the release of glucose from glycogen. After that, epinephrine increases the formation of glucose from amino acids or fats in the body. When the amount of blood sugar increases dramatically, the pancreas will automatically produce insulin to control blood sugar. The failure of the pancreas to produce insulin at this time and coupled with a poor lifestyle, lack of exercise, long-term stress leads to a series of metabolic diseases such as DM (Heraclides et al., 2009)

\section{CONCLUSIONS}

The result showed that from 3 measurements of the level of psychological stress and the risk of type 2 diabetes mellitus,it concluded stress has a relationship with the risk of a person suffering from type 2 diabetes mellitus in the next 10 years. Research suggests that a person who unable to control his stress for a sufficiently long period of time may be at risk for developing type 2 diabetes mellitus. Type 2 diabetes is preceded by a period of marked changes in glucose regulation.

\section{Conflict of Interest}

The authors declare that they have no conflict of interest.

\section{ACKNOWLEDGEMENTS}

This study was supported and funded by the Indonesia Ministry of Research and Technology/National
Research and Innovation Agency. Authors acknowledge to all 6 Government office in Bukittinggi, West Sumatra Indonesia, including participant and management.

\section{REFFERENCES}

American Diabetes Association (2017) Standards of Medical Care in Diabetes. Diakses retrieve from: https://professional.diabetes.org/sites/professional .diabetes.org/files/media/standardofcare2017fulld eckfinal_0.pdf

Anggina, L., Ali, H \& Pandhit. (2010). Hubungan antara dukungan sosial keluarga dengan kepatuhan pasien Diabetes Mellitus dalam melaksanakan program diet Di Poli Penyakit Dalam RSUD Cibabat Cimahi. Journal Penelitian Kesehatan Suara Forikes, hal 1-9.

Diagnosis and Classification of Diabetes Mellitus (2011). Diakses. American Diabetes Association $(A D A)$ retrieve from : www.care.Diabetes journals.org/content/34/Supplement_1/S62.ful

Harris, M. L., Oldmeadow, C., Hure , A., Luu, J., Loxton, D. \& Attia, J. (2017), Stress increases the risk of type 2 diabetes onset in women: A 12-year longitudinal study using causal modeling. PLoS ONE 12(2)pp: e0172126

Heraclides, A., Chandola, T., Witte, D. R. \& Brunner, E. J. (2009) Psychosocial Stress at Work Doubles the Risk of Type 2 Diabetes in Middle-Aged Women: evidence from the Whitehall II study. Diabetes Care.32(12) pp:2230-2235

Isnaini, Ratnasari (2012) Faktor risiko mempengaruhi kejadian Diabetes mellitus tipe dua. Retrieve from: https://www.researchgate.net/publication/327725 771_faktor_risiko_mempengaruhi_kejadian_Diab etes_mellitus_tipe_dua

Kusnanto, Sundari, P.M., Asmoro, C.P. Hidayat Arifin Hubungan Tingkat Pengetahuan dan Diabetes SelfManagement dengan Tingkat Stres Pasien Diabetes Melitus JKI, 22(1), pp:31-42

Labindjang, F.I , Kadir, S. \& Salamanja V. (2015). Hubungan Stres Dengan Kadar Glukosa Darah Pada Penderita Diabetes Mellitus Di Puskesmas Bolangitang Barat Kabupaten Bolaang Mongondow Utara. Retrieve from: https:// repository.ung.ac.id/skripsi/show/841411126/ 
hubungan-stres-dengan-kadar-glukosa-darah-padapenderita-diabetes-mellitus-di-puskesmasbolangitang-barat-kabupaten-bolaang-mongondow -utara.html

Marcondes, F.K., Neves, V.J., Costa1, R., Sanches, A., Cunha, T.S., Moura, M.J.C.S., Tanno, A.P. and Casarini, D.E. (2019). Dyslipidemia induced by stress. Diakses. Retrieve from: https://www. researchgate.net/publication/221923784_Dyslipid emia_Induced_by_Stress

PERKENI (2015) Konsensus Pengelolaan dan Pencegahan Diabetes Melitus Tipe 2 Di Indonesia 2015. Jakarta: PB Perkeni

Ridayani, Santri, \& Naim (2018). Gambaran hasil pemeriksaan kadar High Density Lipoprotein (HDL) dan Low Density Lipoprotein (LDL) pada penderita obesitas di Rumah Sakit Umum Daerah Syekh Yusuf Kabupaten Gowa. Diakses pada tanggal 10 Oktober 2020 melalui uit.e-journal.id

Siregar \& Hidajat (2017)Faktor Yang Berperan Terhadap Depresi, Kecemasan Dan Stres Pada Penderita Diabetes Melitus Tipe 2: Studi Kasus Puskesmas Kecamatan Gambir Jakarta Pusat.Diakses pada tanggal retrieve from: http://ojs.atmajaya.ac.id/ index.php/manasa/article/view/621

Sui, H., Sun, N., Zhan, L., Lu, X., Chen, T. \& Mao, X. (2016). Association between Work-Related Stress andRisk for Type 2 Diabetes: A Systematic Review and Meta-Analysis of Prospective Cohort Studies. PLoS One; 11(8):e0159978

Virtanen, M., Ferrie, J.E., Tabak, A.G., Akbaraly, T.N., Vahtera, J., Singh-Manoux, A. \& Kivimäki M.(2014). Psychological Distress and Incidence of Type 2 Diabetes in High-Risk and Low-Risk Populations: The Whitehall II Cohort Study. Diabetes Care; 37(8);pp:2091-7

Widodo, A. (2012). Stres pada pasien diabetes mellitus tipe-2 dalam melaksanakan program diet di Klinik Penyakit Dalam RSUP Dr. Kariadi Semarang. Medica Hospitalia, 1 (1), pp:53-56

World Health Organization. (2017). Diabetes. Genewa: World Health Organization.

Yoo, H. \& Franke, W.D. (2010). Stress and cardiovascular disease risk in female law enforcement officer. International Archives of Occupational and Environmental Health, 84(3), pp:279-286 